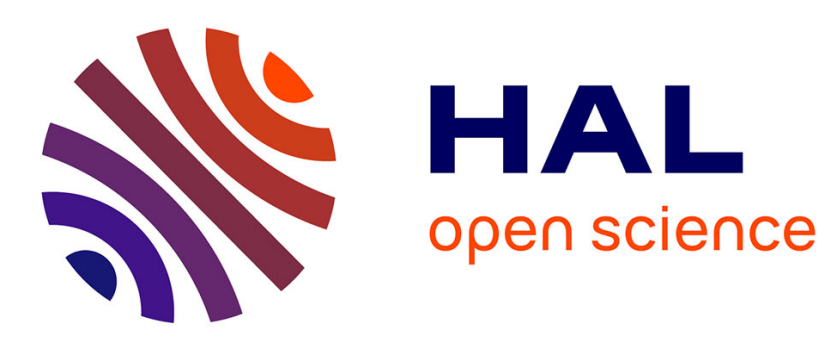

\title{
Angiogenin and endothelial cells
}

Josette Badet, Fabrice Soncin, Denis Barritault

\section{To cite this version:}

Josette Badet, Fabrice Soncin, Denis Barritault. Angiogenin and endothelial cells. Experientia Supplementum, 1992, Angiogenesis, 61, pp.235-238. 10.1007/978-3-0348-7001-6_36 . hal-01645089

\section{HAL Id: hal-01645089 \\ https://hal.science/hal-01645089}

Submitted on 22 Nov 2017

HAL is a multi-disciplinary open access archive for the deposit and dissemination of scientific research documents, whether they are published or not. The documents may come from teaching and research institutions in France or abroad, or from public or private research centers.
L'archive ouverte pluridisciplinaire HAL, est destinée au dépôt et à la diffusion de documents scientifiques de niveau recherche, publiés ou non, émanant des établissements d'enseignement et de recherche français ou étrangers, des laboratoires publics ou privés. 
Title: ANGIOGENIN AND ENDOTHELIAL CELLS.

Authors: Josette BADET, Fabrice SONCIN and Denis BARRITAULT.

Laboratoire de Biotechnologie des Cellules Eucaryotes - Université Paris Val de Marne - Créteil - FRANCE. 
Angiogenin is a potent blood vessel-inducing polypeptide that has a unique ribonucleolytic activity. Initially identified from tumor cells conditioned medium through its ability to induce neovascularization in the chick embryo chorioallantoic membrane assay [1], angiogenin has also been purif ied from normal plasma [2] which suggested that it might be involved in endothelium homeostasis. Angiogenin is highly homologous to pancreatic ribonuclease $A$ with $68 \%$ amino acid sequence homology and conserved essential active site residues [3]. However, angiogenin is inactive in standard ribonuclease assays but has a ribonucleolytic specificity toward ribosomal and transfer RNAs [4]. This enzymic activity might be relevant to the process of anglogenesis since a functional active site seems necessary for the expression of its angiogenic property [5], however, it appears not to be sufficient [6].

\section{Interactions of anglogenin with endothelial cells}

Using recombinant human anglogen in produced by Rhône-Poulenc Santé and shown to be angiogenic, in vivo, both in the chick chorloallantoic membrane and the rabbit cornea $[7,8]$, we have demonstrated the presence of high affinity binding sites on endothelial cells from calf pulmonary artery (CPAE), bovine aorta, cornea and adrenal cortex capiliary that could not be detected on Chinese hamster lung fibroblasts [9]. Receptors have also been reported on bovine brain capillary endothelial cells [10]. The interactions on CPAE cells displayed an apparent dissociation constant in the nanomolar range and involved about 200,000 angiogenin molecules per cell [9]. This number, that varies with the cell density, does not necessarily represent a number of receptors. However, it includes receptors since angiogenin, added to cultured cells, triggers off a series of intracellular events in endothelial cells such as a transient increase in 1,2-diacylglycerol [11] and activation of phospholipase A2 [12], and in vascular smooth muscle cells, activation of phospholipase $\mathrm{C}$ and a rapid cholesterol

32 esterification [13]. Besides, angiogenin might modulate mitogenic 33 stimuli $[10,14]$.

34 Angiogenin has also been snown to interact with low-affinity/high 35 capacity specific binding sites on CPAE cells as well as on extracellular 
1 matrix. This second family of interactions, with an apparent 2. dissociation constant of $0.2 \mu \mathrm{M}$, involved millions of molecules [9].

3 An angiogenin-binding protein has been recently identified on bovine 4 endothelial cells as a dissociable cell-surface component of 42-KDa 5 released by treating the cells with heparan sulfate [15].

6

7 Inhibition of angiogenin properties by Placental Ribonuclease 8 inhibitor

9 Placental ribonuclease inhibitor (PRI) is a tight binding inhibitor of 10 both the ribonucleolytic and angiogenic activities of angiogenin [16] 11 with an inhibition constant value, $\mathrm{Ki}$, in the femtomolar range [17]. This 12 inhibitor also abolishes angiogenin binding to CPAE cells [9]. However, $13 \mathrm{PRI}$ is an intracellular regulatory protein and although immunoreactivity 14. has been detected in normal human plasma [18], there is not yet any 15 experimental evidence for angiogenin/inhibitor circulating complexes. 16

17 Effects of copper metal ions on angiogenin binding to endothelial cells and to ribonuclease inhibitor

19 Divalent copper, a modulator of angiogenesis [19], has been shown to 20 induce a severalfold increase in specific cell-bound angiogenin and to 21 reverse PRl-induced inhibition of angiogenin binding to CPAE cells $[8,9]$. 22. Furthermore, divalent copper metal ions inhibits angiogenin 23. ribonucleolytic activity towards tRNA substrate [20].

\section{Discussion}

The variety of copper interactions with angiogenin properties is 28 indeed puzzling. It might reflect a tight regulation of angiogenin 29 functions necessary to balance its angiogenic potency with its high 30 intravascular concentration. Copper also interacts with heparin and the 31 angiogenic growth factor FGF [21], and appears, from other reported 32 data, to modulate angiogenesis somehow [19]. At this point, it is worth 33 noting that copper is required for other fundamental events such as 34 central nervous system development, bone and connective tissue 35 biosynthesis, electron transport and antioxidant protection where it 
1 acts as a prosthetic group [22]. Because of angiogenin peculiarities, 2 studies on its mechanism of action should lead the way to a better 3 knowledge of the blochemical events involved in angiogenesis. 4

5 In summary, modulation of angiogenin functions might involve 6 interactions with cell-surface receptors, binding protein and 7 extracellular matrix components, tight-binding inhibition of both its 8 ribonucleolytic activity and cell binding by ribonuclease inhibitor under 9 the overall influence of divalent copper, a modulator of angiogenesis. 


\section{REFERENCES}

1 Fett JW, Strydom DJ, Lobb RR, Alderman EM, Bethune JL, Riordan JF, Vallee BL: Isolation and characterization of angiogenin, an angiogenic protein from human carcinoma cells. Biochemistry 1985;24:54805486.

2 Shapiro R, Strydom DJ, Olson KA, Vallee BL: Isolation of angiogenin from human plasma. Biochemistry 1987;26:5141-5146.

3 Vallee BL, Riordan JF: Chemical and biochemical properties of human angiogenin. Adv Exp Med Biol 1988;234:41-53.

4 Shapiro R, Riordan JF, Vallee BL: Characteristic ribonucleolytic activity of human angiogenin. Biochemistry 1986;25:3527-3532.

5 Riordan JF, Vallee BL: Human angiogenin, an organogenic protein. $\mathrm{Br}$ Cancer 1988;57:587-590.

6 Hallahan TW, Shapiro R, Vallee BL: Dual site model for the organogenic activity of angiogenin. Proc Nati Acad Sci USA 1991;88:2222-2226.

7 Denèfle $P$, Kovarik S, Guitton J-D, Cartwright T, Mayaux J-F: Chemical synthesis and expression of a gene coding for human angiogenin in Escherichia coli and conversion of the product into its active form. Gene 1987;56:61-70.

8 Badet $J$, Soncin F, N'Guyen T, Barritault D: In vivo and in vitro studies of anglogenin-a potent anglogenic factor. Blood Coag Fibrin 1990;1:721-724.

9 Badet J, Soncin F, Guitton J-D, Lamare O, Cartwright T, Barritault D: Specific binding of angiogenin to calf pulmonary artery endothelial cells. Proc Natl Acad Sci USA 1989;86:8427-8431.

10 Chamoux M, Dehouck MP, Fruchart JC, Spik G, Montreuil J, Cecchelli R: Characterization of angiogenin receptors on bovine brain capillary endothelial cells. Biochem Biophys Res Commun 1991;176:833-839.

11 Bicknell R, Vallee BL: Angiogenin activates endothelial cell phospholipase C. Proc Natl Acad Sci USA 1988;85:5961-5965.

12 Bicknell R, Vallee BL: Angiogenin stimulates endothelial cell prostacyclin secretion by activation of phospholipase A2. Proc Natl Acad Sci USA 1989;86:1573-1577. 
13 Moore F, Riordan JF: Angiogenin activates phospholipase $C$ and elicits a rapid incornoration of fatty acid into cholesterol esters in vascular smooth muscle cells. Biochemistry 1990;29:228-233.

14 Heath WF, Moore F, Bicknell R, Vallee BL: Modulation of mitogenic stimuli by anglogenin correlates with in vitro phosphatidylinositol biphosphate synthesis. Proc Natl Acad Sci USA 1989;86:2718-2722

15 Hu G-F, Chang S-I, Riordan JF, Vallee BL: An angiogenin-binding prote in from endothelial cells. Proc Natl Acad Sci USA 1991;88:22272231.

16 Shapiro R, vallee BL: Human placental ribonuclease innibitor abolishes both angiogenic and ribonucleolytic activities of angiogenin. Proc Natl Acad Sci USA 1987;84:2238-2241.

17 Lee FS, Shapiro R, Vallee BL: Tight-binding inhibition of angiogenin and ribonuclease $A$ by placental ribonuclease inhibitor. Biochemistry 1989;28:225-230.

18 Feldman M, Kohtz DS, Kleinberg DL: Isolation and characterization of monoclonal antibodies against ribonuclease inhibitor. Biochem Biophys Res Commun 1988;157:286-294.

19 Folkman J, Klagsbrun M: Angiogenic factors. Science 1987;235:442447.

20 Lee FS, Vallee BL: Characterization of ribonucleolytic activity of angiogenin towards tRNA. Biochem Biophys Res Commun $1989 ; 161: 121-126$.

21 Shing Y: Heparin-copper biaffinity chromatography of Fibroblast Growth Factors. J Biol Chem 1988;263:9059-9062.

22 Ettinger M: Cellular biochemistry of copper and inherited defects of copper metabolism. Life chem Rep 1987;5:169-186.

\section{Mailing address:}

1 Josette BADET

2 Université Paris XII- L.B.C.E.

3 Avenue du Général de Gaulle

3494010 Creteil - FRANCE

35 Tel. 33-1-48 996098 / Fax. 33-1-42070603 


\section{ACKNOWLEDGEMENTS:}

2 We thank Or. T. Cartwright and his collaborators for recombinant

3 human angiogenin (Rhône-Poulenc Santé). This work was

4 supported by funds from "l'Association de la Recherche sur le

5 Cancer" (grant $n^{\circ} 6231$ ) and "le Ministère de l'Education

6 Nationale". JB. was supported by "l'Institut National de la Santé

7 et de la Recherche Médicale" and F.S. by "le Ministère de la

8 Recherche et de la Technologie". 